\title{
PUBLIC LISTING AND GORPORATE SOCIAL RESPONSIBILITY FROM A SUSTAINABILITY RISK MANAGEMENT PERSPECTIUE
}

\author{
Ruitao $\mathrm{Li}^{{ }^{1} \text { and Fang } \mathrm{Hu}^{2}}$ \\ 1) Chongqing University, Chongqing, China \\ ${ }^{2)}$ Griffith University, Queensland, Australia
}

Please cite this article as:

$\mathrm{Li}, \mathrm{R}$. and $\mathrm{Hu}, \mathrm{F} ., 2020$. Public Listing and Corporate

Social Responsibility from a Sustainability Risk

Management Perspective. Amfiteatru Economic, 22(55),

Article History

Received: 29 March 2020

Revised: 21 May 2020

Accepted: 3 June 2020

pp. 808-822.

DOI: $10.24818 / \mathrm{EA} / 2020 / 55 / 808$

\begin{abstract}
The current global economic development faces social and environmental challenges, such as climate change and environmental pollution, which requires firms to be more socially responsible. Due to the fast-growing corporate social responsibility (CSR) consciousness and concerns of individual investors in the stock market, the newly listed firms are likely to face greater legitimacy pressure from stakeholders in China. This institutional environment is quite suitable to explore how public listing influences firms' CSR performance and its potential mechanism. Using a sample of Chinese IPO firms for the years 2012-2016 and a multiple regression model controlling firm fixed effect and time fixed effect, we find that there is a significant and sustained increase in CSR performance after IPO. Further analyses also show that this increase in CSR performance is more pronounced in heavily polluting industries, especially at firms that are covered by more securities analysts, and more media. Overall, these findings suggest that CSR can be served as an instrument to manage sustainable development risk for IPO firms to meet the social and environmental expectations of various stakeholders. By highlighting the prominent role that public listing plays in firms' CSR decisions, this study draws the regulator's attention to promoting sustainable economic development in other developing countries like China, which lack mature CSR culture and institutional environment.
\end{abstract}

Keywords: Corporate social responsibility, sustainability, initial public offering, heavily polluting industry, analyst, media coverage

JEL Classification: G32, Q51, M14

\footnotetext{
* Corresponding author, Ruitao Li - ruitaoli@cqu.edu.cn
} 


\section{Introduction}

In recent years, corporate social responsibility (CSR) has become a crucial determinant of corporate sustainable development (Kolk and Tulder, 2010; Lu et al., 2019). Prior research indicates that CSR can improve employee relationships, increase firm competitiveness, and decrease financing costs (Greening and Turban, 2000; Kitzmueller and Shimshack, 2012; Gong et al., 2020). Given the importance of CSR, economists and policymakers have paid increasing attention to drivers of CSR. While a rich body of academic literature has investigated the determinants of CSR, direct empirical evidence on the effect of public listing on CSR is scant. Public listing makes firms expose to wider stakeholders that greatly change the institutional environment in which firms operate. For example, investors prefer to hold shares of firms with higher CSR performance (Nofsinger et al., 2019). Analysts also tend to give higher ratings to socially responsible firms (Ioannou and Serafeim, 2015). Therefore, the changes in firms' operating environment arising from public listing might have a significant impact on their CSR engagement. In this paper, we attempt to extend the related literature by exploring how public listing influences firms' CSR performance and its potential mechanism.

According to the legitimacy theory, firms' sustainable survival is dependent on whether their value system is congruent with the value system of the large social system in which the firms operate. The previous study suggests that firms are exposed to the pressure of stakeholders, such as investors, customers, suppliers, and employees (Carroll, 1979). Thus, when the firms enter the financial market through the IPO, they naturally face increasing pressure from a variety of stakeholders who concern the firms' legitimacy. If stakeholders perceive firms' CSR performance as underqualified, a firm will face threats to its legitimacy (Davis, 1973). Such legitimacy threats might lead to a poor image, customer dissatisfaction, hiring issues, litigation, and stricter regulation, among other causes (Ameer and Othman, 2012), all of which increase the sustainability risk of firms. A large body of research indicates that CSR performance is one of the most important factors to maintain firms' legitimacy in society (Muthuri and Gilbert, 2011), and to build up a good reputation against sustainability risk shocks (Bebbington et al., 2008). Thus, we argue that the newly listed IPO firms may adopt CSR engagement as an instrument of sustainability risk management to enhance their legitimacy.

China is a suitable setting to examine how public listing impacts firms' CSR performance. First, China does not have a mature culture for corporate social responsibility and institutional environment like developed countries, and thus environmental pollution in China remains a quite severe problem. Many listed firms have been embedded with much environmental pollution before entering the capital market through IPO because of lacking public scrutiny. The public listing exposes the company to greater environmental pressures from stakeholders, which make them more prone to improve CSR performance to meet stakeholders' social and environmental expectation. Second, since the 18th National Congress of the Communist Party of China, the importance of environmental protection is unprecedentedly highlighted by the government. The consciousness of CSR has been largely increasing in Chinese society, which also motivates IPO firms to use CSR practices to minimize sustainability risk. Third, the vast majority of participants in the Chinese stock market are individual investors who are increasingly concerned about firms' CSR performance. As the potential shareholders of the newly listed IPO firms, these individual investors have an increasing need for sustainability risk management at IPO firms. 
By investigating how public listing influences firms' CSR decisions, this study makes the following contributions to the literature. First, this study adds to the growing literature on the external drivers of CSR (Haniffa and Cooke, 2005; Liao et al., 2018). We show that public listing, as an exogenous change of market environment, has a significant impact on a firm's CSR choice. Second, we provide new evidence that the positive relation between IPO and CSR performance is more pronounced in heavily polluting industries, especially when they are exposed to greater media or analyst pressure. In doing so, this study contributes to legitimacy theory research on CSR (Branco and Rodrigues, 2006; Panwar et al., 2014), and suggests that motivations behind CSR of IPO companies might be capturing the interests of various market participants and stakeholders. Third, this paper contributes to the economic consequences of public listing by IPO. Prior literature focuses on the impact of IPO on firms' profitability (Pástor et al., 2009), innovation quality (Bernstein, 2015), and product market (Chemmanur et al., 2010). Our study complements prior literature by examining the effect of public listing on firms' CSR performance.

The rest of this paper is organized as follows: Section 1 reviews the related literature and develops our hypothesis. Section 2 describes the research methodology. Section 3 presents the empirical results. Section 4 concludes.

\section{Literature review and hypothesis development}

\subsection{The effect of public listing on CSR performance}

Traditionally, business firms seek to maximize profits to create wealth for shareholders. However, as the increasing deterioration of the ecological environment puts forward severe challenges to the sustainable development of socio-economy, firms are expected to take extra responsibilities for sustainability. Drawing upon the legitimacy theory, the firm's operating objectives need to conform to the stakeholder value preferences. Thus, firms should integrate the social and environmental considerations in their strategies and management practices to respond to the current or future interests of stakeholders (Sobczak and Havard, 2015). Prior research shows that CSR engagement helps to resolve conflicts among stakeholders, build up a good reputation (Bebbington et al., 2008), and reduce the likelihood of regulatory or legislative sanctions (Hillman and Keim, 2001). Bhardwaj et al. (2018) show that consumers prefer to buy products or services from a company with higher CSR performance even if other competitor companies' products or services are available at a similar cost and quality. The above literature shows that CSR practice brings a variety of benefits to firms' sustainability development, indicating that firms can use CSR activities to manage sustainable risk.

Public listing brings firms from private to the public market, which exposes the firms to the interests of wider stakeholders, such as investors, analysts, mass media, regulators, and so on. As the IPO firms need to gain or maintain their legitimacy in society, they had to comply with the regulations, norms, values, and beliefs established by these various stakeholders (Suchman, 1995). Firms with better CSR performance are enjoying a higher stock valuation (Boubakri et al., 2016), lower financing costs (Gong et al., 2020), and a higher rating from security analysts (Ioannou and Serafeim, 2015), suggesting that external stakeholders are particularly concerned about firms' CSR performance. Since public listing has brought greater legitimacy threats to IPO firms, IPO firms are motivated to engage in CSR practices 
to lower sustainable risk. Boubakri et al. (2016) find that cross-listed firms exhibit better CSR performance. In particular, since the 18th National Congress of the Communist Party of China in 2012, the environmental protection issue is unprecedentedly emphasized to build a "green China", which has greatly enhanced the consciousness of CSR in the national wide. Due to the lack of mature CSR culture and a strong institutional environment in China, many firms had serious pollution to the environment before public listing. The newly listed firms face greater legitimacy pressure from wider stakeholders. Thus, they tend to improve their CSR performance to meet the social and environmental expectations of the public after the IPO. Based on this analysis, we propose the first hypothesis as follows:

- Hypothesis 1. Firms' CSR performance is positively associated with public listing.

\subsection{The CSR performance in heavily polluting industries}

As mentioned in the previous literature, legitimacy pressure from stakeholders varies with different industries. For instance, the legitimacy of certain industries (such as the mining industry) is challenged by stakeholders with more concern on the environmental pollution problem because those industries have environmental issues rooted in history (Bansal and Cleland, 2004). Due to the heavy harm to public health and security, those so-called heavily polluting industries, remaining controversial, draw stakeholder's more attention after going public, facing greater legitimacy threats. Evidence from the literature suggests that firms in heavily polluting industries appear to be more active in CSR practice, especially when they are at risk of litigation (Grougiou et al., 2016). Jo and $\mathrm{Na}$ (2012) also argue that the firms in "controversial" industries actively engage in CSR activities for sustainability risk management. Boubakri et al. (2016) find that cross-listing firms are more active in CSR activities when their industries face higher litigation risks. Taken together, we argue that firms in heavily polluting industries are facing greater legitimacy pressure from stakeholders, as a result, they are more likely to engage in CSR activities. Thus, we propose the second research hypothesis as follows. More formally:

- Hypothesis 2. Firms operating in heavily polluting industries increase their CSR performance more than firms in non-heavily polluting industries after public listing.

\subsection{The effect of public attention on CSR performance}

The mass media has a significant impact on monitoring. For instance, firms' stakeholders who lack direct links mainly follow the firms through the mass media (Zyglidopoulos et al., 2012). In other words, media coverage exposes firms to more scrutiny from stakeholder groups (Siegel and Vitaliano, 2007). The media coverage will bring up additional visibility and responsibility at firms in heavily polluting industries, which increases their need for sustainability risk management. Therefore, media coverage will further motivate these newly listed firms operating in heavily polluting industries to adopt more CSR practices, thereby reducing legitimacy threats and managing sustainability risk. Thus, we propose the following hypothesis $3 \mathrm{a}$.

- Hypothesis 3a. The positive effect of public listing on CSR engagement in heavily polluting industries is more pronounced when there is more media coverage. 
The literature also points out that securities analysts serve as a type of information intermediate through which external stakeholders can track the firms (Ioannou and Serafeim, 2015). High analyst coverage has drawn more stakeholder attention and increased legitimacy pressure. Thus, the IPO firms covered by more securities analysts are facing greater external monitoring pressure to improve CSR performance. In addition, analysts value firms with higher CSR performance and give them higher ratings, which means CSR engagement is seen as an efficient instrument to manage sustainability risk. With the higher analyst coverage, as predicted, the newly listed firms in heavily polluting industries have a stronger motivation to engage in CSR activities to lower legitimacy threats. Therefore, we propose the following hypothesis $3 \mathrm{~b}$.

- Hypothesis 3b. The positive effect of public listing on CSR engagement in heavily polluting industries is more pronounced when more analysts follow the IPO firms.

\section{Research methodology}

\subsection{Contextual framework}

Corporate social responsibility performance. We collect the CSR data from the Hexun website (www.hexun.com), which is the main data source to evaluate the CSR performance of Chinese listed firms. Hexun's CSR data is extensively used in previous studies (Xiong et al., 2016; Gong et al., 2020). Hexun's CSR data is evaluated based on the prospectus, annual report, and the evaluation system uses 13 secondary-level and 37 tertiary-level indicators to score firms' CSR performance. Hexun's CSR scores range from 0 to 100 . We have established two variables to represent CSR performance, specifically CsrS and CsrN. The variable CsrS is the original CSR score from the Hexun website. Another variable CsrN is the natural $\log$ of the CSR score for the distribution of CSR scores not evenly distributed, so the logarithmic processing makes the regression results more reliable. In this study, we use $\mathrm{CsrN}$ as the dependent variable in the min tests and use CsrS for robustness checks.

Public listing. Our paper aims to examine the effect IPO on CSR performance by comparing IPO firms' CSR performance before and after public listing. We constructed the variable to measure the post-IPO period, to be specific, the variable Post-listing equals to 1 after public listing and equals to 0 before the listing.

Heavily polluting industries. The Chinese Ministry of Ecology and Environment issued the guideline for environmental information disclosure of listed firms on September 2010, in which some industries are classified as heavy polluters, such as thermal power, cement, steel, electrolytic aluminium, metallurgy, petro-chemistry coal, chemical, building materials, paper, pharmacy, brewing, fermentation, tanning, textile, and mining. Our variable Pollute equals 1 if the firm belongs to the above heavily polluting industries which are consistent with the previous literature ( $\mathrm{Su}, 2019)$.

Control variable. Following the prior research (Boubakri et al., 2016; Jha and Cox, 2015; Liao et al., 2018; Gong et al., 2020), we introduce a set of control variables that might affect CSR performance, including SIZE, ROA, LEV, BIG4, TOP1, BOARD, and INDIRECTOR. Detailed variable definitions are shown in table no. 1. 
Table no. 1. Variable measurements

\begin{tabular}{|c|c|}
\hline Variable Name & Definition \\
\hline $\mathrm{CsrS}$ & The original CSR score from the Hexun CSR Database. \\
\hline $\mathrm{CsrN}$ & The natural log of CSR score. \\
\hline Post-listing & It equals to 1 after IPO and equals to 0 before listing through IPO. \\
\hline Pollute & $\begin{array}{l}\text { A dummy variable equals } 1 \text { if firms belong to heavily polluting } \\
\text { industries, and } 0 \text { otherwise. }\end{array}$ \\
\hline SIZE & Natural logarithm of firms' total assets. \\
\hline ROA & Return on assets. \\
\hline LEV & Total liabilities scaled by total assets. \\
\hline BIG4 & $\begin{array}{l}\text { A dummy variable equals } 1 \text { if firms audited by big four } \\
\text { international audit firms, and } 0 \text { otherwise. }\end{array}$ \\
\hline TOP1 & The proportion of shares held by the first shareholder. \\
\hline BOARD & The natural logarithm of the number of directors. \\
\hline INDIRECTOR & The proportion of independent directors on the board. \\
\hline
\end{tabular}

\subsection{Data}

We employ the Chinese IPO firms listed from 2012 to 2016 as our sample. In our empirical model, we aim to compare the two-years CSR performance surrounding the company's listing year. So, we need the data for at list two years prior to or post to the listing year. For this reason, we extend the sample year from 2010-2018. Besides the CSR data from the Hexun website begins in 2010, which is the reason we set the sample starting point. Financial data and other firm-specific information are drawn from the Chinese Stock Market and Accounting Research (CSMAR) database, which is the largest financial database in China. In addition, consistent with existing literature, we clean our sample data by excluding financial firms and delete firm-years with any data missing. Finally, all continuous variables are winsorized at the 1 st and 99th percentiles.

\subsection{Modeling}

Drawing upon the previous research (Pástor et al., 2009; Wies and Moorman, 2015), we construct the following model to investigate whether and how public listing affects firms' CSR performance:

$\mathrm{CsrN}_{\mathrm{it}}=\beta_{1}$ Post-listing $_{\mathrm{it}}+$ Control $_{\mathrm{it}}+\alpha_{\mathrm{i}}+\alpha_{\mathrm{j}}+\varepsilon$

CsrN $_{i t}=\beta_{1}$ Post-listing $_{i t}+\beta_{2}$ Post-listing $_{i t} *$ Pollute $_{i t}+\beta_{3}$ Pollute $_{i t}+$ Control $_{i t}+\alpha_{i}+\alpha_{j}+\varepsilon$

where:

$\mathrm{CsrN}_{\mathrm{it}} \quad$-the natural $\log$ of CSR score

Post-listing $_{\text {it }} \quad-$ a dummy variable equals to 1 after public listing, and 0 otherwise

Post-listing $_{i t} *$ Pollute $_{i t}-$ the interaction of Post-listing ${ }_{i t}$ and Pollute $_{i t}$

Pollute $_{i t} \quad-$ A dummy variable represents a firm in heavily polluting industries

Control $_{\text {it }} \quad-$ the control variables mentioned above 
We will test the hypothesis 1 using the model (1) above. If public listing has a positive impact on firms' CSR performance, we expect that the coefficient of Post-listing is significantly positive. Then, our study introduces the interaction term of Post-listing and Pollute in the model (2) to test hypothesis 2 and hypothesis 3. The positive coefficient of Postlisting*Pollute will support our hypothesis.

In order to obtain a more reliable regression result, we use the fixed effects model, which specifically controls the time fixed effects $\left(\alpha_{i}\right)$ and the firm fixed effects $\left(\alpha_{\mathrm{j}}\right)$. We choose to use the fixed-effect model for two reasons. One reason is that the fixed effect model can rules out time-invariant unobservable firm characteristics that may be confounded with both the decision of public listing and firms' CSR performance (Pástor et al., 2009; Wies and Moorman, 2015). The other reason is that we conduct the Hausman test that is compatible with the use of the fixed-effect model.

\section{Results and discussions}

\subsection{Results}

Table no. 2 shows the trend analysis of CSR performance before and after the IPO. In panel A, both the original CSR score (CsrS) and the natural logarithmic of the CSR score (CsrN) are higher after the IPO. The average CSR score (CsrS) is 19.88 and 21.31 in the Pre-IPO period ( 2 years before and 1 year before IPO), which are lower than those in the Post-IPO period (1 year after IPO is 25.31 and 2 years after IPO is 23.65). The trend of CsrN is consistent. In panel B, the mean of CsrN for firms in the Pre-IPO period is 3.01 and that for the Post-IPO period is 3.13. The mean difference is 0.12 and is significant at the $1 \%$ level, supporting hypothesis 1 . Panel $\mathrm{C}$ of Table 2 reports the Spearman correlation matrix for the main variables included in our regression models. Our independent variable Post-listing is significantly positively correlated with our dependent variable $\mathrm{CsrN}$ and $\mathrm{CsrS}$, which further supports that public listing has a positive impact on firms' CSR performance.

Table no. 2. CSR performance around the IPO

\begin{tabular}{|c|c|c|c|c|c|}
\hline \multicolumn{6}{|c|}{ Preliminary variable test } \\
\hline \multicolumn{6}{|c|}{ Panel A: The annual change trend of CSR performance } \\
\hline & IPOyear(-2) & IPOyear (-1) & IPOyear (0) & IPOyear $(+1)$ & IPOyear $(+2)$ \\
\hline $\mathrm{N}$ & 629 & 709 & 710 & 707 & 699 \\
\hline CsrS (mean) & 19.88 & 21.31 & 25.93 & 25.31 & 23.65 \\
\hline CsrN (mean) & 2.97 & 3.04 & 3.22 & 3.16 & 3.10 \\
\hline \multicolumn{6}{|c|}{ Panel B: Univariate testing (CSR performance before and after IPO) } \\
\hline & Pre-IPO(-2,- & & Post-IPO $(1,2$ & Difference & T-statistic \\
\hline CsrS (mean) & 20.64 & & 24.48 & 3.84 & $13.67^{* * *}$ \\
\hline CsrN (mean) & 3.01 & & 3.13 & 0.12 & $10.47^{* * *}$ \\
\hline \multicolumn{6}{|c|}{ Panel C: Correlation matrix } \\
\hline & Post-listing & & CsrS & CsrN & \\
\hline Post-listing & 1 & & & & \\
\hline CsrS & $0.253^{* * *}$ & & 1 & & \\
\hline CsrN & $0.196^{* * *}$ & & $0.906^{* * *}$ & 1 & \\
\hline
\end{tabular}

Notes: IPOyear (-1) indicates the year before the IPO, and so on. Our data is an unbalanced panel, with a total of 710 IPO firms, but the CSR score of an IPO firm might be missing in a year. For example, only 699 firms exist CSR scores in IPOyear(+2), and 11 firms' CSR score is missing this year. 
Table no. 3 presents the descriptive statistics for the main variables in our paper. The average value of CsrS is 22.61, which is consistent with previous literature using the CSR data from Hexun. The mean value of $\mathrm{CsrN}$ after natural logarithmic processing is 3.07. The average of Pollute is 0.20 , indicating that $20 \%$ of the IPO firms are operating in heavily polluting industries. In addition, the average SIZE, ROA, and LEV are 20.89, 0.10, and 0.36, which is consistent with the previous literature based on the sample of Chinese listed firms. Other firm-specific variable statistics are also similar to previous research in China.

Table no. 3. Descriptive statistic of main variables

\begin{tabular}{|l|l|l|l|l|l|l|}
\hline \multicolumn{1}{|c|}{ Variable } & \multicolumn{1}{c|}{$\mathbf{N}$} & \multicolumn{1}{c|}{ Mean } & \multicolumn{1}{c|}{ SD } & \multicolumn{1}{c|}{ Min } & \multicolumn{1}{c|}{ Median } & \multicolumn{1}{c|}{ Max } \\
\hline CsrS & 2744 & 22.61 & 7.60 & 1.83 & 21.62 & 76.05 \\
\hline CsrN & 2744 & 3.07 & 0.31 & 0.60 & 3.07 & 4.33 \\
\hline Post-listing & 2744 & 0.51 & 0.50 & 0.00 & 1.00 & 1.00 \\
\hline Pollute & 2744 & 0.20 & 0.40 & 0.00 & 0.00 & 1.00 \\
\hline SIZE & 2744 & 20.89 & 0.96 & 19.10 & 20.78 & 23.73 \\
\hline ROA & 2744 & 0.10 & 0.06 & -0.00 & 0.08 & 0.32 \\
\hline LEV & 2744 & 0.36 & 0.17 & 0.05 & 0.35 & 0.76 \\
\hline BIG4 & 2744 & 0.03 & 0.18 & 0.00 & 0.00 & 1.00 \\
\hline TOP1 & 2744 & 0.44 & 0.18 & 0.11 & 0.42 & 0.90 \\
\hline BOARD & 2744 & 2.28 & 0.27 & 1.10 & 2.30 & 2.77 \\
\hline INDIRECTOR & 2744 & 0.39 & 0.09 & 0.20 & 0.38 & 0.75 \\
\hline
\end{tabular}

Notes: The continuous variables are winsorized at the 1st and 99th percentiles to mitigate the influence of outliers.

Table no. 4 reports the regression results to test hypothesis 1 and hypothesis 2 in our paper. In Columns (1), the coefficients on Post-listing are positive and statistically significant ( 0.161 with a t-value of 3.504), indicating that firms significantly increase their CSR performance after IPO. These results support our hypothesis 1 . To identify whether the public listing has long-term impacts on CSR performance, we use three dummy variables for identification. To be specific, Pre 1 equals 1 in the first year before IPO and equals 0 for other years. Post 1 equals 1 in the first year after IPO and 0 for other years, Post 2 equals 1 in the second year after IPO and 0 for other years where the second year before IPO is set as the benchmark. In model (1), we replace the independent variable Post-listing with Pre1, Post1, and Post2, and then conduct the regression. In column 2, the coefficients of Pre1, Post1, and Post2 are 0.105, 0.275, and 0.186, which are all significant at the $1 \%$ level. Thus, we can find that public listing has a long-term positive effect on CSR performance. Thus, hypothesis 1 is further confirmed.

Taken together, these results are consistent with the view of Goergen et al. (2019), who argues that "listed firms are more likely to have a CSR statement than their non-listed counterparts". Previous literature also provides some evidence in other countries. For example, Haniffa and Cooke (2005) report that the listing status encourages companies to improve CSR performance in Malaysian. Monteiro and Beatriz (2010) argue that the fact that a company is listed on the stock market are positively related to the extent of environmental disclosure in Portugal. In addition, Boubakri et al. (2016) also suggest that the cross-listing in the US has a positive impact on firms' CSR performance. These studies, in both developed and emerging economies, confirm the positive impact of financial market listing on firms' CSR performance is universal. 
In Column (3) of table no. 4, we test the impact of heavily polluting industries on the relationship between public listing and CSR performance. The coefficient on Postlisting*Pollute are $0.059(\mathrm{t}$-value $=1.755)$. The significant positive coefficient suggests that the environmental pressure of heavily polluting industries is a key factor affecting the improvement of CSR performance after public listing, thus supporting our hypothesis 2 . To examine the long-term impact of public listing on CSR performance in heavily polluting industries, the post-listing was divided into three dummy variables interacting with Pollute. These three dummy variables are Pre1, Post1, and Post 2 who's definitions are described in above. In column (4) of table no. 4, the coefficients of these three interaction terms all significantly positive at the $1 \%$ level, which confirms that the newly listed firms in heavily polluting industries improving their CSR performance are long-term strategies. These findings show that the CSR engagement serves as an instrument to manage sustainable development risk, which further support hypothesis 2 .

Overall, the findings are consistent with the argument that industry-level characteristics have a large impact on firms' CSR performance. Jo and $\mathrm{Na}$ (2012) argue that the firms in "controversial" industries positively engage in CSR activities for sustainability risk management, which is economically and statistically significant. Tiron-Tudor et al. (2019) also find that firms belonging to an environmentally sensitive industry like Oil \& Gas and Utilities disclose more CSR information than other industries. Many other researchers have shown similar results (Fatma et al., 2019; $\mathrm{Wu}$ and $\mathrm{Hu}, 2019$ ). This paper finds that Chinese IPO firms operating in heavily polluting industries also adopt positive CSR strategies and it's a long-term strategy.

Table no. 4. The effect of public listing on CSR performance

\begin{tabular}{|c|c|c|c|c|}
\hline & & Depen & ariable $=C$ & \\
\hline & (1) & (2) & (3) & (4) \\
\hline Post-listing & $\begin{array}{l}0.161^{* * * *} \\
(3.504)\end{array}$ & & $\begin{array}{l}0.217^{* * * *} \\
(7.546)\end{array}$ & $\begin{array}{l}0.153^{* * * *} \\
(3.603)\end{array}$ \\
\hline Pre1 & & $\begin{array}{l}0.105^{\text {**** }} \\
(6.065)\end{array}$ & & \\
\hline Post1 & & $\begin{array}{l}0.275^{* * * *} \\
(8.028)\end{array}$ & & \\
\hline Post2 & & $\begin{array}{l}0.186^{* * * *} \\
(4.935)\end{array}$ & & \\
\hline Post-listing*Pollute & & & $\begin{array}{l}0.059^{*} \\
(1.755)\end{array}$ & \\
\hline Pre1*Pollute & & & & $\begin{array}{l}0.106^{* * *} \\
(3.209)\end{array}$ \\
\hline Post1*Pollute & & & & $\begin{array}{l}0.177^{* * * *} \\
(5.307)\end{array}$ \\
\hline Post $2 *$ Pollute & & & & $\begin{array}{l}0.116^{* * * *} \\
(3.330)\end{array}$ \\
\hline Pollute & & & $\begin{array}{l}-0.045 \\
(-0.809)\end{array}$ & $\begin{array}{l}-0.135 \\
(-0.552)\end{array}$ \\
\hline Control variable & Yes & Yes & Yes & Yes \\
\hline Year-fixed/ Firm-fixed & Yes & Yes & Yes & Yes \\
\hline $\mathrm{R}^{2}$ & 0.153 & 0.181 & 0.269 & 0.165 \\
\hline$N$ & 2744 & 2744 & 2744 & 2744 \\
\hline
\end{tabular}

Notes: The values of the $t$ statistics are in parentheses. *, ** and *** indicate the regression coefficients are significant at levels of 10\%, 5\%, and 1\%, respectively. 
Table no. 5 shows the empirical results for hypothesis $3 \mathrm{a}$ and hypothesis $3 \mathrm{~b}$. Specifically, firms with higher media coverage face greater public pressure, so we divide the sample into two groups based on media coverage degree. Based on media reports number greater than the median of the full sample, we divide firms into the high media coverage group and the low media coverage group. The sample is grouped by high/ or low analyst coverage. In column (1), the positive coefficient on Post-listing*Pollute is significant at the 5\% level in the subsample with higher media coverage, and in column (2) the coefficient on Postlisting*Pollute is not significant in the subsample with lower media coverage, which proves the hypothesis $3 \mathrm{a}$. In column (3), the coefficients on Post-listing*Pollute is significant at $1 \%$ level in the subsample with higher analyst coverage, whereas the coefficient on this interaction term is not significant in the subsample with lower analyst coverage in column (4). Thus, the hypothesis of $3 \mathrm{~b}$ is supported.

In summary, despite the lack of a mature CSR culture and institutional environment in China, public monitoring pressure has a positive impact on firms' CSR performance, showing that the legitimacy pressure of stakeholders is effective in the emerging economy. Another interesting research (Dumitru et al., 2017) shows the evidence from Romania and Poland. Considering that Romania's CSR disclosure is mainly driven by regulations, while Poland, with a more mature CSR culture, mainly has voluntary CSR disclosure. They examine the CSR disclosure of 40 listed firms in the two countries before the European Directive 2014/95/EU came into force, and find that Romania scored higher on CSR reporting items covered by national regulations than Poland. In contrast, Poland scored higher than Romania on CSR reporting items beyond the scope of regulations. Taken together, firms' CSR engagement is forced in different ways in emerging economies, despite the weak institutional environment associated with social responsibility.

Table no. 5. The effect of public attention

\begin{tabular}{|l|l|l|l|l|}
\hline \multirow{4}{*}{} & \multicolumn{4}{|c|}{ Dependent Variable=CsrN } \\
\cline { 2 - 5 } & Media coverage & \multicolumn{3}{|c|}{ Analyst coverage } \\
\cline { 2 - 5 } & High & Low & High & Low \\
\cline { 2 - 5 } & $(1)$ & $(2)$ & $(3)$ & $(4)$ \\
\hline Post-listing & $0.246^{* * *}$ & $0.175^{* * *}$ & $0.244^{* * *}$ & $0.127^{* *}$ \\
& $(6.965)$ & $(4.160)$ & $(7.877)$ & $(2.331)$ \\
\hline Post-listing*Pollute & $0.177^{* *}$ & 0.030 & $0.149^{* * *}$ & 0.011 \\
& $(2.394)$ & $(0.821)$ & $(2.715)$ & $(0.263)$ \\
\hline Pollute & -0.035 & $-0.119^{* *}$ & -0.015 & $-0.126^{*}$ \\
& $(-0.334)$ & $(-2.117)$ & $(-0.196)$ & $(-1.923)$ \\
\hline Control variable & Yes & Yes & Yes & Yes \\
\hline Year-fixed/ Firm-fixed & Yes & Yes & Yes & Yes \\
\hline $\mathrm{R}^{2}$ & 0.285 & 0.293 & 0.262 & 0.313 \\
\hline$N$ & 930 & 1814 & 1351 & 1393 \\
\hline
\end{tabular}

Notes: The values of the $t$ statistics are in parentheses. *, ** and *** indicate the regression coefficients are significant at levels of 10\%, 5\%, and 1\%, respectively.

\subsection{Robustness checks and endogenous}

In this section, we conduct several robustness tests for our baseline results. First, we employ alternative measurement of public listing, which includes the impact of the IPO year. To be 
specific, Post-listing1 equals to 1 if in the year of listing, in the first year after listing, and in the second year after listing, and equals to 0 in the first year before listing, and in the second year before listing. As shown in table no. 6, in column 1-2, the coefficients on Post-listing1 are both significant at the $1 \%$ level, which further strengthens the robustness of our conclusions.

Second, we introduce the difference-in-differences(DID) model to solve endogenous problems. Here, we take the listed firms as the control group, and the specific matching method is to find a listed firm for each IPO firm in its IPO year as the matching sample, which is called propensity score matching (PSM). Specifically, we are interested in the interaction term of Treat and Post. The specific variables are defined as follows: Treat is equal to 1, if the sample belongs to an IPO firm, it is equal to 0 if it is a listed firm. After the IPO firm is listed, Post is equal to 1 , otherwise, it is 0 , and the listed firms in the matching sample are equal to 1 since the matching year before it was 0 . In column 1 , the coefficient on Treat*Post is 0.167 and significant at the $1 \%$ level, and the coefficient on Treat*Post is still significantly positive at the $1 \%$ level (4.211 with a t-value of 8.647). Overall, by comparing with firms that have already been listed, we still observe that the significant positive impact of public listing on CSR performance.

Table no. 6. Alternative measures and difference-in-differences(DID) analysis

\begin{tabular}{|c|c|c|c|c|}
\hline & \multicolumn{2}{|c|}{ Alternative measures } & \multicolumn{2}{|c|}{ PSM+DID } \\
\hline & CsrS & CsrN & CsrS & CsrN \\
\hline & (1) & (2) & (3) & (4) \\
\hline Post-listing1 & $\begin{array}{l}0.266^{* * *} \\
(11.681)\end{array}$ & $\begin{array}{l}6.374^{* * *} \\
(10.312)\end{array}$ & & \\
\hline Treat & & & $\begin{array}{l}-0.048^{* *} \\
(-2.190)\end{array}$ & $\begin{array}{l}-2.480^{* * * *} \\
(-5.376)\end{array}$ \\
\hline Treat*Post & & & $\begin{array}{l}0.167^{\text {*** }} \\
(6.347)\end{array}$ & $\begin{array}{l}4.211^{* * * *} \\
(8.647)\end{array}$ \\
\hline Post & & & $\begin{array}{l}0.007 \\
(0.219)\end{array}$ & $\begin{array}{l}0.150 \\
(0.257)\end{array}$ \\
\hline Control variable & Yes & Yes & Yes & Yes \\
\hline Year-fixed/ Firm-fixed & Yes & Yes & Yes & Yes \\
\hline $\mathrm{R}^{2}$ & 0.193 & 0.177 & 0.335 & 0.303 \\
\hline$N$ & 3454 & 3454 & 4828 & 4930 \\
\hline
\end{tabular}

Notes: The values of the $t$ statistics are in parentheses. $*, * *$ and $* * *$ indicate the regression coefficients are significant at levels of 10\%, 5\%, and 1\%, respectively.

\subsection{Discussions}

Table no. 7 presents the literature which focuses on the impact of the stock market listing on firms' CSR performance in both developed and developing countries. The literature has demonstrated that the public listing has positive impacts on firms' CSR performance. This paper focuses on the impact of IPO on CSR performance, which is different from other studies focusing on cross-listing or a single industry. Meanwhile, our research has some limitations. For example, we focus on a single country -Chinese IPO firms. Relatively, China has the advantage of data, there are rarely pre-IPO CSR scores for companies provided in 
any database in other countries. Briefly, through the view of literature, we can conclude that the positive impact of the stock market listing on CSR performance is a global phenomenon.

Table no. 7. List of prior literature about public listing and CSR performance

\begin{tabular}{|l|l|l|}
\hline \multicolumn{1}{|c|}{ Literature } & \multicolumn{1}{|c|}{ Country } & \multicolumn{1}{c|}{ Research Findings } \\
\hline $\begin{array}{l}\text { Haniffa and } \\
\text { Cooke (2005) }\end{array}$ & Malaysian & $\begin{array}{l}\text { They find that multiple listing is significantly } \\
\text { positively related to corporate social disclosure. }\end{array}$ \\
\hline $\begin{array}{l}\text { Monteiro and } \\
\text { Beatriz (2010) }\end{array}$ & Portugal & $\begin{array}{l}\text { They argue that a firm is listed on the stock market is } \\
\text { positively related to the extent of environmental } \\
\text { disclosure. }\end{array}$ \\
\hline Kiliç (2016) & Turkey & $\begin{array}{l}\text { The author shows that multiple exchange listing has a } \\
\text { positive impact on the corporate social disclosure of } \\
\text { the bank industry. }\end{array}$ \\
\hline $\begin{array}{l}\text { Goergen et al. } \\
(2016)\end{array}$ & 31 countries & $\begin{array}{l}\text { They show that publicly-listed firms are more likely to } \\
\text { have CSR codes than privately-held firms. }\end{array}$ \\
\hline $\begin{array}{l}\text { Boubakri et al. } \\
(2016)\end{array}$ & $\begin{array}{l}\text { The United } \\
\text { States }\end{array}$ & $\begin{array}{l}\text { They report that Cross-listed firms have better CSR } \\
\text { performance than non-cross-listed peers. }\end{array}$ \\
\hline $\begin{array}{l}\text { Goergen et al. } \\
(2019)\end{array}$ & 31 countries & $\begin{array}{l}\text { The finding is that listed firms are more likely to have } \\
\text { a CSR statement. }\end{array}$ \\
\hline $\begin{array}{l}\text { Matuszak and } \\
\text { Różańska } \\
\text { (2019) }\end{array}$ & Poland & $\begin{array}{l}\text { Their findings show that the significant determinants } \\
\text { for explaining online CSR disclosure level of bank } \\
\text { industry are the size and being listed }\end{array}$ \\
\hline
\end{tabular}

\section{Conclusions}

This study examines firms' CSR performance in pre/post IPO periods and finds that public listing has a significant positive impact on CSR performance. These findings support the view of Goergen et al. (2019) who claim that the listed firms are more likely to have a CSR statement than their non-listed counterparts. Considering the industry characteristics, further tests provide evidence that the increase in CSR performance is more pronounced in heavily polluting industries, especially at firms covered by more securities analysts, and more media. Therefore, in emerging economies like China, where a CSR culture and institutional environment remains weak, companies would conform to the social and environmental expectations of stakeholders and improve their sustainability risk management strategies, following the public listing in the stock market.

The findings have practical implications for the China Securities Regulatory Commission (CSRC). The relatively poor CSR performance before listing indicates that a large number of non-listed firms in China need to improve their CSR performance. For example, regulators may request IPO firms to provide CSR reports of $3-5$ years prior to listing. Given a large number of firms applying for public listing in China, this policy will be very effective in promoting economic and social sustainability by increasing disclosure. In addition, our research has important implications for investors. While the positive CSR performance of firms in heavily polluting industries can be opportunistic, the investors need to be cautious about opportunistic CSR disclosure. Finally, in developing countries, the pressure from stakeholders to the firms' CSR performance is limited. We call for the regulator's interests in strengthening the legislative and institutional environment. 
Our study has some limitations. First, our research sample is consisting of only Chinese IPO firms. The findings of this paper may be not generalized in other countries although it's a universal issue. Second, the CSR score provided by Hexun website is based on the prospectus and annual report of the listed company. It is not based on a standalone CSR report. As the disclosure is voluntary, the CSR score may be missing and incomplete. Third, the sample period is from 2012 to 2016 . Our conclusions just fit for the situation in recent years when China has implemented stricter environmental protection laws and regulations.

Overall, we believe that the CSR performance of IPO firms is an interesting topic worthy of further research, and we try to propose some possible directions in the future study. For example, we can explore more data in the content of the prospectus and further assess how investors and analysts respond to IPO firms' social responsibility actions. We can examine the impact of CSR performance on IPO underpricing or post-IPO stock returns, testing the economic benefits of CSR practice. In addition, we can investigate the opportunistic behaviour of CSR practices and how opportunistic behaviour affects long-term environmental performance. These potential areas will be of interest for further research.

\section{References}

Ameer, R. and Othman, R., 2012. Sustainability practices and corporate financial performance: A study based on the top global corporations. Journal of Business Ethics, 108(1), pp. 61-79.

Bebbington, J., Larrinaga, C. and Moneva, J. M., 2008. Corporate social reporting and reputation risk management. Accounting, Auditing \& Accountability Journal, 21(3), pp. 337-361

Branco, M. C. and Rodrigues, L. L., 2006. Corporate social responsibility and resource-based perspectives. Journal of Business Ethics, 69(2), pp. 111-132.

Bansal, P. and Clelland, I., 2004. Talking trash: Legitimacy, impression management, and unsystematic risk in the context of the natural environment. Academy of Management journal, 47(1), pp.93-103.

Bernstein, S., 2015. Does going public affect innovation. The Journal of Finance, 70(4), pp.1365-1403.

Bhardwaj, P., Chatterjee, P., Demir, K. D. and Turut, O., 2018. When and how is corporate social responsibility profitable. Journal of Business Research, 84, pp. 206-219.

Boubakri, N., El Ghoul, S., Wang, H., Guedhami, O. and Kwok, C. C., 2016. Cross-listing and corporate social responsibility. Journal of Corporate Finance, 41, pp. 123-138.

Carroll, A. B., 1979. A three-dimensional conceptual model of corporate performance. Academy of Management Review, 4(4), pp. 497-505.

Chemmanur, T. J., He, S. and Nandy, D. K., 2010. The going-public decision and the product market. The Review of Financial Studies, 23(5), pp. 1855-1908.

Da Silva Monteiro, S. M. and Aibar $\square$ Guzmán, B., 2010. Determinants of environmental disclosure in the annual reports of large companies operating in Portugal. Corporate Social Responsibility and Environmental Management, 17(4), pp. 185-204.

Davis, K., 1973. The case for and against business assumption of social responsibilities. Academy of Management Journal, 16(2), pp. 312-322. 
Dumitru, M., Dyduch, J., Gușe, R. G. and Krasodomska, J., 2017. Corporate reporting practices in Poland and Romania-an ex-ante study to the new non-financial reporting European Directive. Accounting in Europe, 14(3), pp. 279-304.

Fatma, M., Khan, I. and Rahman, Z., 2019. Striving for legitimacy through CSR: An exploration of employees' responses in controversial industry sector. Social Responsibility Journal. 15(7), pp. 924-938.

Gong, G., Huang, X., Wu, S., Tian, H. and Li, W., 2020. Punishment by Securities Regulators, Corporate Social Responsibility and the Cost of Debt. Journal of Business Ethics, 12(1) pp. 1-20.

Goergen, M., Chahine, S., Wood, G. and Brewster, C., 2016. Public listing, context and CSR: The effects of legal origin. Journal of Comparative International Management, 19(1), pp. 35-59.

Goergen, M., Chahine, S., Wood, G. and Brewster, C., 2019. The relationship between public listing, context, multi-nationality and internal CSR. Journal of Corporate Finance, 57, pp. 122-141.

Grougiou, V., Dedoulis, E. and Leventis, S., 2016. Corporate social responsibility reporting and organizational stigma: The case of "sin" industries. Journal of Business Research, 69(2), pp. 905-914.

Greening, D. W. and Turban, D. B., 2000. Corporate social performance as a competitive advantage in attracting a quality workforce. Business \& Society, 39(3), pp. 254-280.

Haniffa, R. M. and Cooke, T. E., 2005. The impact of culture and governance on corporate social reporting. Journal of Accounting and Public Policy, 24(5), pp. 391-430.

Hart, S. L. and Ahuja, G., 1996. Does it pay to be green? An empirical examination of the relationship between emission reduction and firm performance. Business Sstrategy and the Environment, 5(1), pp. 30-37.

Hillman, A. J. and Keim, G. D., 2001. Shareholder value, stakeholder management, and social issues: What's the bottom line. Strategic Management Journal, 22(2), pp. 125-139.

Hong, H. and Kacperczyk, M., 2009. The price of sin: The effects of social norms on markets. Journal of Financial Economics, 93(1), pp. 15-36.

Ioannou, I. and Serafeim, G., 2015. The impact of corporate social responsibility on investment recommendations: Analysts' perceptions and shifting institutional logics. Strategic Management Journal, 36(7), pp. 1053-1081.

Jo, H. and Na, H., 2012. Does CSR reduce firm risk? Evidence from controversial industry sectors. Journal of Business Ethics, 110(4), pp. 441-456.

Jha, A. and Cox, J., 2015. Corporate social responsibility and social capital. Journal of Banking \& Finance, 60, pp. 252-270.

Kitzmueller, M. and Shimshack, J., 2012. Economic perspectives on corporate social responsibility. Journal of Economic Literature, 50(1), pp. 51-84.

Kiliç, M., 2016. Online corporate social responsibility (CSR) disclosure in the banking industry: Evidence from Turkey. International Journal of Bank Marketing, 34(4), pp. 550-569.

Kolk, A. and Tulder, R. V., 2010. International business, corporate social responsibility and sustainable development. International Business Review, 19(2), pp. 119-125. 
Liao, L., Lin, T. P. and Zhang, Y., 2018. Corporate board and corporate social responsibility assurance: Evidence from China. Journal of Business Ethics, 150(1), pp. 211-225.

Lu, J., Ren, L., He, Y., Lin, W. and Streimikis, J., 2019. Linking Corporate Social Responsibility with Reputation and Brand of the Firm. Amfiteatru Economic, 21(51), pp. 442-460.

Matuszak, Ł. and Różańska, E., (in press). Online corporate social responsibility (CSR) disclosure in the banking industry: evidence from Poland. Social Responsibility Journal, Vol. ahead-of-print No. ahead-of-print

Muthuri, P. C., Merrill, C. B. and Hansen, J. M., 2009. The relationship between corporate social responsibility and shareholder value: An empirical test of the risk management hypothesis. Strategic Management Journal, 30(4), pp. 425-445.

Muthuri, J. N. and Gilbert, V., 2011. An institutional analysis of corporate social responsibility in Kenya. Journal of Business Ethics, 98(3), pp. 467-483.

Nofsinger, J. R., Sulaeman, J. and Varma, A., 2019. Institutional investors and corporate social responsibility. Journal of Corporate Finance, 58(1), pp. 700-725.

Panwar, R., Paul, K., Nybakk, E., Hansen, E. and Thompson, D., 2014. The legitimacy of CSR actions of publicly traded companies versus family-owned companies. Journal of Business Ethics, 125(3), pp. 481-496.

Pástor, L', Taylor, L. A. and Veronesi, P., 2009. Entrepreneurial learning, the IPO decision, and the post-IPO drop in firm profitability. The Review of Financial Studies, 22(8), pp. 3005-3046.

Siegel, D. S. and Vitaliano, D. F., 2007. An empirical analysis of the strategic use of corporate social responsibility. Journal of Economics \& Management Strategy, 16(3), pp. 773-792.

Sobczak, A. and Havard, C., 2015. Stakeholders' influence on French Unions' CSR strategies. Journal of Business Ethics, 129(2), pp.311-324.

$\mathrm{Su}, \mathrm{K}$., 2019. Does religion benefit corporate social responsibility? evidence from china. Corporate Social Responsibility and Environmental Management, 126(8), pp. 156-172.

Suchman, M. C., 1995. Managing legitimacy: Strategic and institutional approaches. Academy of Management Review, 20(3), pp. 571-610.

Tiron-Tudor, A., Nistor, C.S., Ștefănescu, C.A. and Zanellato, G., 2019. Encompassing NonFinancial Reporting in A Coercive Framework for Enhancing Social Responsibility: Romanian Listed Companies' Case. Amfiteatru Economic, 21(52), pp. 590-606.

Wies, S. and Moorman, C., 2015. Going Public: How Stock Market Listing Changes Firm Innovation Behavior. Journal of Marketing Research, 52(5), pp. 694-709.

Wu, C. M. and Hu, J. L., 2019. Can CSR reduce stock price crash risk? Evidence from China's energy industry. Energy Policy, 128(11), pp. 505-518.

Xiao, Y., Faff, R., Gharghori, P. and Lee, D., 2013. An empirical study of the world price of sustainability. Journal of Business Ethics, 114(2), pp. 297-310.

Xiong, B., Lu, W., Skitmore, M., Chau, K. W. and Ye, M., 2016. Virtuous nexus between corporate social performance and financial performance: A study of construction enterprises in China. Journal of Cleaner Production, 129, pp. 223-233.

Zyglidopoulos, S. C., Georgiadis, A. P., Carroll, C. E., \& Siegel, D. S. (2012). Does media attention drive corporate social responsibility? Journal of Business Research, 65(11), pp. 1622-1627. 